A N N A L E S

UNIVERSITATIS MARIAE CURIE-SKŁODOWSKA

LUBLIN - POLONIA

VOL. LXVI, 1

SECTIO G

2019

Uniwersytet Wrocławski

MIROSŁAW SADOWSKI

miroslaw.sadowski@uwr.edu.pl

ORCID: 0000-0002-0077-8651

\title{
Kilka uwag o nauczaniu społecznym papieża Franciszka
}

Remarks on the Social Teaching of Pope Francis

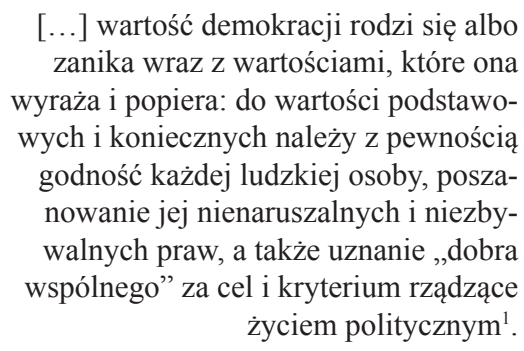

Pisanie do Księgi pamiątkowej jest często uważane za obowiązek w sytuacji, gdy dostojny Jubilat jest osobą uznaną przez środowisko. W przypadku, w którym Jubilat jest również osobą szanowaną i lubianą, obowiązek zamienia się w przyjemność. $\mathrm{Z}$ tą drugą sytuacją mam do czynienia, składając tekst dla uczczenia Profesora Lecha Dubela.

Ostatnich kilka lat spędziłem na badaniu prawa islamu, ale ponieważ - jak głosi ludowa mądrość - ciągnie wilka do lasu, postanowiłem chociaż na chwilę wrócić do swoich wcześniejszych dociekań naukowych, czyli do papieskiego nauczania społecznego. Ich efektem są poniższe rozważania.

Papieskie nauczanie społeczne w zgodnej opinii badaczy zostało zapoczątkowane przez Leona XIII, zasiadającego na stolicy Piotrowej w latach 1878-1903. To właśnie ten papież wskazał na problemy (pierwszym z nich była tzw. kwestia

1 Encyklika papieża Jana Pawła II Evangelium Vitae - o wartości i nienaruszalności życia ludzkiego, ogłoszona 25 marca 1995 r., 70. 
robotnicza, nazywana też społeczną), dla których jego następcy próbowali z większym lub mniejszym powodzeniem znaleźć rozwiązanie. Do głównych zagadnień podejmowanych przez następców Świętego Piotra zaliczyłbym: prawo do pracy i godziwego wynagrodzenia, prawo własności, prawo do tworzenia związków zawodowych ${ }^{2}$, sprawiedliwość, prawo oraz inne zagadnienia, które z czasem stały się zaczynem papieskiej koncepcji praw człowieka (wyrosłej z doktryny prawa naturalnego), która konsekwentnie odrzucała wszelkie próby ideologizacji tej idei. Na marginesie warto przypomnieć wciąż niedocenione zasługi Piusa XII w tej materii. Papież ten już w 1942 r. poczynił niemal prorocze spostrzeżenie ${ }^{3}$, że „Współczesne poczucie prawne zostało sfałszowane i zniekształcone przez głoszenie i uprawianie pozytywizmu i utylitaryzmu, które krępują łańcuchami społeczeństwo i wydają na służbę poszczególnym grupom, zespołom czy ruchom, których programy ideowe wyznaczają i wykreślają drogę prawodawstwu i obyczajom sądowym"4.

W moim przekonaniu fundament, na którym opiera się nauczanie papieży w kwestiach społecznych, stanowią dwie kategorie: dignitas humana i bonum commune $e^{5}$ W oparciu o te idee papieska nauka społeczna rozważa, a także rozstrzyga całe spektrum fundamentalnych zagadnień dotyczących religii, moralności, filozofii, kultury, prawa, polityki, a nawet ekologii. Papieże próbowali wprowadzić do debaty publicznej - w kontekście ludzkiej godności i dobra wspólnego - takie klasyczne idee i wartości, jak: prawda, dobro, sprawiedliwość, sumienie, miłość, miłosierdzie czy cnota. Uważam, że w papieskim nauczaniu społecznym zarówno idee dignitas humana, jak i bonum commune są ściśle powiązane z zasadami subsydiarności, solidaryzmu społecznego, koncepcją organicznej koncepcji społeczeństwa, ideą prawa naturalnego i wolności człowieka, który jest istotą społeczną. Jak wspomniałem wyżej, to właśnie Leon XIII wszystkie te kwestie podniósł jako pierwszy.

Jak na tym tle prezentuje się nauczanie papieża Franciszka? ${ }^{6}$ Zanim przejdę do analizy, wypada słów kilka nakreślić o samym bohaterze, ponieważ jego

2 Por. M. Sadowski, Państwo w doktrynie papieża Leona XIII, Wrocław 2002, s. 134-141.

3 Należy je postrzegać w świetle wydarzeń z kwietnia 2018 r. dotyczących batalii o Alfiego Evansa.

4 Por. Papież Pius XII, Con sempre nuova freschezza - krucjata społeczna, orędzie na Boże Narodzenie, 24 grudnia 1942 r., https://ekai.pl/dokumenty/oredzie-na-boze-narodzenie-1942 [dostęp: 17.05.2019], 89. Następnie zaś podkreślił, że ,stosunki człowieka do człowieka, jednostki do społeczeństwa, do władzy, do obowiązków obywatelskich, dalej stosunek społeczności i władzy do poszczególnych ludzi, powinny być oparte na jasno określonych założeniach prawnych i chronione w miarę potrzeby przez prawo z pomocą władzy sądowniczej" (ibidem, 92).

5 M. Sadowski, Godność człowieka i dobro wspólne w papieskim nauczaniu społecznym (1878-2005), Wrocław 2010, passim.

6 W niniejszych rozważaniach świadomie pomijam nauczanie społeczne Benedykta XVI, ponieważ w mojej ocenie nie przyniosło jakichś spektakularnych wypowiedzi papieskich w kwestiach społecznych. 
pochodzenie i biografia wywarły znaczny wpływ na poglądy, które głosi jako papież.

Jorge Mario Bergoglio urodził się 17 grudnia 1936 r. w Buenos Aires (stolicy Argentyny) jako jedno z pięciorga dzieci włoskich emigrantów pochodzących z Piemontu. W młodości studiował chemię, jednak już w 1958 r. wstąpił do Towarzystwa Jezusowego, podjął formację zakonną i studia seminaryjne. Odznaczający się wyjątkowymi zdolnościami, w 1967 r. rozpoczął studia teologiczne, święcenia kapłańskie przyjął 13 grudnia 1969 r., a cztery lata później złożył ostatnie śluby zakonne, uczynił to zatem jako osoba dojrzała, miał bowiem wówczas 37 lat. Następnie był mistrzem nowicjatu w Villa Barilari, profesorem Wydziału Teologii i rektorem Colegio Máximo de San José w San Miguel, członkiem konsulty prowincji zakonnej San Miguel oraz prowincjałem Argentyny. W 1992 r. został biskupem pomocniczym Buenos Aires, a w 1998 r. - arcybiskupem tej diecezji. W 2001 r. Jan Paweł II mianował go kardynałem. Podczas konklawe w kwietniu 2005 r. kardynał Jorge Bergoglio był wymieniany jako jeden z potencjalnych faworytów do następstwa po zmarłym Janie Pawle II. W latach 2005-2011 kardynał Bergoglio był przewodniczącym Konferencji Episkopatu Argentyny. W dniu 13 marca 2013 r., po trwającym dwa dni konklawe, został wybrany papieżem i przyjął imię Franciszek.

Papież Franciszek włada kilkoma językami: hiszpańskim, włoskim, niemiec$\mathrm{kim}^{7}$, francuskim, łaciną oraz angielskim i portugalskim. Na studiach uczył się także klasycznej greki. Papież z Argentyny jest pierwszym papieżem z kontynentu amerykańskiego oraz pierwszym spoza Europy od czasu papieża Grzegorza III (pontyfikat w latach 731-741), który pochodził z Syrii. Jest również pierwszym jezuitą wybranym na papieża i pierwszym zakonnikiem od czasu papieża Grzegorza XVI (pontyfikat w latach 1831-1846).

Pierwsze wrażenie związane z wyborem Bergoglio na papieża dotyczyło starego rzymskiego powiedzenia, zgodnie z którym papież nie wie trzech rzeczy: jak to rzeczywiście jest z tym ubóstwem franciszkanów, ile jest żeńskich zgromadzeń zakonnych i co myślą jezuici. Moje zaskoczenie wzbudziła zwłaszcza ta trzecia kwestia, która w przypadku Franciszka stała się kompletnie nieaktualna i mogła zapowiadać istotne zmiany w Kościele rzymskokatolickim.

Wiele kwestii po wyborze Bergoglio na papieża było definiowanych przy użyciu liczebnika „pierwszy”: pierwszy jezuita na tronie papieskim, pierwszy papież z Ameryki Południowej, pierwszy od stuleci spoza Europy (zatem, w domyśle, słabo orientujący się w sprawach tego kontynentu) oraz pierwszy, który

7 W tym języku obronił w latach 80 . XX w. rozprawę doktorską, która miała dotyczyć myśli Romano Guardiniego, ale niestety nie zachowała się do naszych czasów. Por. H. Crolly, Bergoglio studierte einst in Frankfurt am Main, www.welt.de/politik/deutschland/article114452124/Bergoglio-studierte-einst-in-Frankfurt-am-Main.html [dostęp: 4.04.2018]. Autorka tego artykułu sugeruje, że praca ta nigdy nie powstała. 
nie pamięta II wojny światowej. Jego jedyne doświadczenie dotyczące tej wojny związane jest z momentem jej zakończenia, który przyniósł ogromną radość matce późniejszego papieża i jej sąsiadce. Przeżycie to musiało być bardzo głębokie i zapaść małemu Bergoglio na zawsze w pamięci, wspominał je bowiem ponad 70 lat po zakończeniu wojny w rozmowie z Dominique Wolton ${ }^{8}$.

Do oficjalnych enuncjacji papieskich, w których są poruszane kwestie społeczne, należy zaliczyć dwie encykliki: napisaną wspólnie z Benedyktem XVI encyklikę Lumen Fidei (Światło wiary) z 29 czerwca 2013 r. oraz encyklikę Laudato si (Pochwalony bądź) z 24 maja 2015 r. (ogłoszoną w święto Zesłania Ducha Świętego), a także dwie adhortacje apostolskie: Evangelii Gaudium (O głoszeniu Ewangelii we wspótczesnym świecie) z 24 listopada 2013 r. oraz posynodalną Amoris Laetitia (Radość miłości) z 19 marca 2016 r. Ponadto należy wskazać tutaj kilka listów apostolskich: Fidelis dispensator et prudens z 24 lutego 2014 r., Misericordiae vultus z 11 kwietnia 2015 r., Come una madre amorevole z 4 czerwca 2016 r., Dobra doczesne z 4 lipca 2016 r. oraz Misericordia et Misera z 20 listopada $2016 \mathrm{r}$.

Jakie treści w swoich wypowiedziach ex cathedra podejmuje Franciszek? Otóż troszczy się o środowisko naturalne, pisze o kompetencjach w kwestiach gospodarczych i finansowych oraz o ochronie osób narażonych na nadużycia seksualne. Wiele mówi również o potrzebie otwarcia się na imigrantów przybywających do Europy.

W jaki sposób obecny papież odnosi się do klasycznych już treści katolickiej nauki społecznej, sformułowanych przez Leona XIII i rozwijanych przez jego następców? Wydaje się, że najpełniej kwestie społeczne zostały zaprezentowane przez Franciszka w encyklice Laudato $s i^{9}$.

Ten obszerny dokument (całość liczy 245 akapitów) ${ }^{10}$ jest dosyć specyficzny i trudny do jednoznacznej oceny. Jego specyfika polega na tym, że autor stara się odnieść do zagadnień niezwykle szczegółowych, wskazując takie kwestie, jak: rośliny modyfikowane genetycznie ${ }^{11}$, ekosystemy Amazonii i dorzecza Konga ${ }^{12}$, zachęcanie do korzystania z energii odnawialnej ${ }^{13}$, a zwłaszcza lasy namorzynowe ${ }^{14}$. W mojej ocenie treści tego typu w istotnym stopniu odwracają uwagę od kwestii

8 Por. Franciszek (papież), D. Wolton, Otwieranie drzwi. Rozmowy o Kościele i świecie, Kraków 2018, s. 238.

9 Świadomie pomijam encyklikę Lumen fidei, dokument ten jest bowiem sygnowany przez Benedykta XVI i Franciszka, trudno zatem rozstrzygnąć, na ile są to poglądy argentyńskiego papieża, a ile treści należy do jego niemieckiego poprzednika.

10 Najpełniejsza encyklika społeczna Jana Pawła II - Centesimus annus z 1991 r. - była co najmniej dwukrotnie krótsza.

11 Laudato si, 133.

12 Ibidem, 38.

13 Ibidem, 52.

14 Ibidem, 39. 
fundamentalnych dla papieskiego nauczania społecznego i nieco je spłycają. Wydaje się, że rolą papieża nie jest szczegółowe wyliczanie problemów związanych $\mathrm{z}$ ekologią.

Podobnie jak jego poprzednicy na papieskim tronie, również Franciszek rozpoczyna swoje rozważania od przypomnienia nauczania poprzedników. Autor Laudato si wskazuje, że problemy ekologii nie były obce Janowi XXIII, Pawłowi VI, Świętemu Janowi Pawłowi II i Benedyktowi XVI ${ }^{15}$. Wymienieni papieże wskazywali, że brak poszanowania dla środowiska naturalnego jest jedną z przyczyn złego funkcjonowania gospodarki światowej ${ }^{16}$. Franciszek wzywa do odpowiedniego korzystania z odkryć będących efektem nowych technologii. W jego ocenie zdobycze techniki przynoszą wiele korzyści człowiekowi, ale mogą rodzić też szereg niebezpieczeństw, a dobro i prawda nie są jedynie konsekwencją technologii i ekonomii ${ }^{17}$.

Apelując o właściwe podejście do paradygmatu technologicznego, papież zachęca do śmiałej rewolucji kulturowej. W jego przekonaniu bowiem:

Nauka i technologia nie są neutralne, ale mogą za sobą pociągać od początku do końca procesu różne intencje i możliwości oraz mogą być określone na różne sposoby. Nikt nie chce wrócić do epoki jaskiniowej, ale konieczne jest spowolnienie marszu, aby obserwować rzeczywistość w inny sposób, gromadzić osiągnięcia pozytywne i zrównoważone, a jednocześnie przywrócić wartości i wielkie cele unicestwione z powodu megalomańskiego niepohamowania ${ }^{18}$.

Papież Franciszek wiele mówi o właściwym kontakcie człowieka z naturą, krytykuje nadmierny antropocentryzm, podobnie zresztą jak jego poprzednicy ${ }^{19}$, i apeluje o prawidłową kulturę ekologiczną.

Oprócz mocnego zaakcentowania kwestii dotyczących ochrony środowiska naturalnego papież odnosi się również do fundamentalnych zagadnień katolickiej nauki społecznej: godności człowieka i dobra wspólnego.

15 Ibidem, 5-6.

16 Ibidem, 6.

17 Franciszek pouczył: „Nie możemy [...] ignorować faktu, że energia jądrowa, biotechnologia, informatyka, znajomość naszego DNA i inne możliwości, które zyskaliśmy, oferują nam straszliwą moc. Co więcej, umożliwiają tym, którzy posiadają wiedzę - a nade wszystko władzę ekonomiczną, aby ją wyzyskiwać - niezwykłe panowanie nad całym rodzajem ludzkim i nad całym światem. Ludzkość nigdy nie miała tyle władzy nad sobą samą i nie ma gwarancji, że dobrze ją wykorzysta, zwłaszcza biorąc pod uwagę sposób, w jaki się nią posługuje. Wystarczy przypomnieć bomby atomowe zrzucone w połowie XX wieku, jak też cały wachlarz technologii wykorzystanych przez nazizm, komunizm i inne reżimy, służących zagładzie milionów ludzi. Nie zapominajmy też, że wojna ma dziś do dyspozycji coraz bardziej śmiercionośne narzędzia. W jakich rękach spoczywa i w jakie ręce może wpaść tak wielka władza? Straszliwie groźne jest to, że leży ona w rękach małej części ludzkości”. Ibidem, 104.

18 Ibidem, 108

19 Ch.E. Curran, The Moral Theology of Pope John Paul II, Washington 2006, s. 13. 
Następca Benedykta XVI kategorię dignitas humana umieszcza w kontekście jej klasycznego rozumienia przez katolicką naukę społeczną. Chrześcijanie uważają, że potwierdzeniem idei człowieka jako obrazu Boga, zawartych już w Starym Testamencie, jest Nowy Testament, gdzie Jezus Chrystus jawi się jako „obraz Boga niewidzialnego", tym samym pojęcie imago Dei jest bezpośrednio odnoszone do Jezusa Chrystusa ${ }^{20}$. Franciszek w encyklice przywołuje także treści biblijne, przypominając, że:

[...] każdy człowiek jest stworzony z miłości, uczyniony na Boży obraz i podobieństwo, a słowa te ukazują nam ogromną godność każdej osoby ludzkiej, która „nie jest tylko czymś, ale kimś”. Jest zdolna poznawać siebie, panować nad sobą, w sposób dobrowolny dawać siebie oraz tworzyć wspólnotę z innymi osobami ${ }^{21}$.

Odwołując się do nauczania Jana Pawła II, papież Franciszek przypomniał, że to właśnie szczególna miłość Boga do każdego człowieka obdarza ludzi nieskończoną godnością ${ }^{22}$. Dla autora encykliki Laudato si ludzka godność jest konsekwencją tego, że człowiek jest obrazem Stwórcy, zatem jako imago Dei współtworzy z Bogiem otaczający go świat. W mojej ocenie stanowisko Franciszka w kwestii ludzkiej godności jest zgodne z tradycją katolickiej nauki społecznej.

Można w tym miejscu postawić tezę, że - podobnie jak jego poprzednicy na papieskim tronie - Franciszek uważa, iż człowiekowi z samego faktu bycia osobą przysługuje niezbywalna godność ${ }^{23}$. Umieszcza ją jednak w kontekście troski człowieka o środowisko naturalne, stwierdzając, że edukacja zmierzająca do „odpowiedzialności za środowisko naturalne może zachęcać do różnych zachowań, które mają bezpośredni i znaczący wpływ na troskę o środowisko". Franciszek zalicza do nich:

[...] unikanie stosowania tworzyw sztucznych i papieru, zmniejszenie zużycia wody, segregowanie odpadów, gotowanie tylko wówczas, gdy będzie można zjeść to, co ugotowano, ostrożne podejście do innych istot żywych, korzystanie z transportu publicznego lub wspólne korzystanie z samochodu przez kilka osób, sadzenie drzew, wyłączanie niepotrzebnego światła itp. ${ }^{24}$

20 A. Scola, Osoba ludzka. Antropologia teologiczna, Poznań 2005, s. 151-190. Zob. również szeroko przeprowadzoną, dogłębną analizę teologiczno-filozoficzną dotyczącą przedmiotu rozważań podjętych w niniejszym opracowaniu - ibidem. Por. także: K. Lehmkühler, Inhabitatio: die Einwohnung Gottes im Menschen, Göttingen 2004, s. 304. W ocenie tej autorki „Jesus Christus ist das Ebenbild des Vaters” (ibidem). W Drugim Liście do Koryntian św. Paweł pisze: „A jeśli nawet Ewangelia nasza jest ukryta, to tylko dla tych, którzy idą na zatracenie, dla niewiernych, których umysły zaślepił bóg tego świata, aby nie olśnił ich blask Ewangelii chwały Chrystusa, który jest obrazem Boga" (II list św. Pawła do Koryntian 3-4).

${ }^{21}$ Laudato si, 65.

22 Ibidem.

23 Ibidem, 29.

${ }^{24}$ Ibidem, 211. 
W papieskiej ocenie troska o środowisko może być aktem miłości wyrażającym naszą godność ${ }^{25}$, ponieważ człowiek jest stworzeniem, które ma prawo do życia i szczęścia w tym świecie, ale jest także obdarzony szczególną godnością.

Z faktu, że Stwórca obdarzył człowieka wyjątkową godnością i inteligencją, wynika obowiązek poszanowania innych istot ${ }^{26}$. Nie należy jednak troski o inne stworzenia mieszać z troską o dignitas humana, a ludzie powinni działać przede wszystkim na rzecz niwelowania nierówności, jakie występują pomiędzy nimi, ponieważ zarówno ludzie zamożni, jak i ubodzy mają jednakową godność wynikającą z faktu stworzenia ich przez tego samego Boga ${ }^{27}$. Te wszystkie działania powinny odbywać się z poszanowaniem dla środowiska naturalnego i religijnego szacunku dla innych stworzeńn ${ }^{28}$.

Drugie fundamentalne dla katolickiej nauki społecznej zagadnienie, jakie pojawia się na kartach encykliki Laudato si, to idea bonum commune. Papież kilkakrotnie nawiązuje do tej kategorii, wiążąc ją z ekologią człowieka - pojęciem wprowadzonym przez Jana Pawła II. Jak stwierdził papież Polak, obok niszczenia środowiska naturalnego należy tu dostrzec jeszcze niebezpieczniejsze niszczenie środowiska ludzkiego przez to, że zbyt mało wagi przywiązuje się do ochrony warunków moralnych prawdziwej „ekologii ludzkiej”. Nie wolno zapominać, że człowiek otrzymał ziemię od Stwórcy, ale również człowiek jest dla siebie samego darem otrzymanym od Boga i dlatego musi respektować naturalną i moralną strukturę, w jaką został wyposażony. Ponieważ człowiek otrzymał od Boga swą istotną godność, posiada dar wznoszenia się ponad wszelki porządek społeczny w dążeniu do prawdy i dobra, równocześnie jednak jest determinowany strukturą społeczną, w której żyje ${ }^{29}$. W przekonaniu Jana Pawła II pierwszą i podstawową komórką „ekologii ludzkiej” jest rodzina, oparta na małżeństwie mężczyzny i kobiety, w której człowiek otrzymuje pierwsze i decydujące wyobrażenia związane z prawdą i dobrem oraz uczy się, jak być osobą. To w rodzinie rodzi się i rozwija dziecko oraz nabywa świadomość własnej godności. Wbrew tzw. kulturze śmierci rodzina stanowi ośrodek kultury życia i jest pierwszym źródłem godności człowieka $^{30}$. W nauczaniu Świętego Jana Pawła II rodzina sprzyja ochronie i poszanowaniu ludzkiej godności i dobra wspólnego.

25 Ibidem.

26 Ibidem, 69.

27 Ibidem, 90, 94.

28 Ibidem, 130. Franciszek przypomniał, że władza człowieka ma swoje granice oraz że sprzeczne z godnością ludzką jest niepotrzebne zadawanie cierpień zwierzętom lub ich zabijanie.

29 Encyklika papieża Jana Pawła II Centesimus annus - rok setny; w setną rocznicę encykliki Leona XII Rerum novarum - 1 V 1991, 38. Por. także: M.S. Joyce, The Voluntary Society and the Moral Order, [w:] A New Worldly Order: John Paul II and Human Freedom, ed. G. Weigel, Washington 1992, s. 97.

${ }^{30}$ Centesimus annus, 39. Tak też: K.R. Himes OFM, Responses to 101 Questions on Catholic Social Teaching, New York 2001, s. 46. 
Podobnie wywodzi papież Franciszek, który naucza, że ludzka ekologia jest nierozerwalnie związana z pojęciem dobra wspólnego. Zasada ta odgrywa główną rolę w etyce społecznej. Definiując dobro wspólne, autor Laudato si przywołał nauczanie społeczne Soboru Watykańskiego II, którego Ojcowie w Konstytucji Duszpasterskiej Gaudium et spes stwierdzili, że bonum commune to suma warunków życia społecznego, które pozwalają „,bądź to grupom, bądź poszczególnym jego [społeczeństwa] członkom pełniej i szybciej osiągnąć ich własną doskonałość"31.

Franciszek, podobnie jak jego poprzednicy, łączy dobro wspólne z ideą ludzkiej godności, stwierdzając, że bonum commune zakłada szacunek dla osoby ludzkiej jako takiej, z jej podstawowymi i niezbywalnymi prawami ukierunkowanymi na jej integralny rozwój. Dla realizacji idei dobra wspólnego niezbędne są dobrobyt i bezpieczeństwo socjalne oraz rozwój różnych ciał pośrednich zgodnie z zasadą subsydiarności. Wśród tych grup pośrednich wyróżnia się zwłaszcza rodzina jako podstawowa komórka społeczna. Papież stwierdza, w ślad za swoimi poprzednikami, że całe społeczeństwo - a w nim zwłaszcza państwo - ma obowiązek bronienia i promowania dobra wspólnego ${ }^{32}$.

Dobro wspólne, wsparte o ideę godności człowieka, sprzyja - przy uwzględnieniu stosowania zasady opcji preferencyjnej dla ubogich - urzeczywistnianiu i ochronie idei praw człowieka ${ }^{33}$. Również te poglądy Franciszka są analogiczne do postulatów głoszonych przez Jana Pawła II. To właśnie ten papież, przypominając chrześcijańskie nauczanie o własności, mówił o niej w kontekście opcji preferencyjnej dla ubogich ${ }^{34}$, pouczając, że dobra materialne zostały pierwotnie przeznaczone dla wszystkich, a prawo do własności prywatnej jest słuszne i konieczne, ale tej zasady nie niweczy, ponieważ własność jest obciążona „hipoteką społeczną" ${ }^{35}$. To znaczy, że dobra doczesne tylko wtedy właściwie wypełniają swoją funkcję społeczną, gdy opierają się na zasadzie powszechnego przeznaczenia dóbr ${ }^{36}$.

31 Laudato si, 156. Por. także: Sobór Watykański II, Konstytucja duszpasterska Gaudium et spes - o kościele w świecie współczesnym, 26.

32 Laudato si, 156.

33 Ibidem, 158.

34 Tak: M.P. Hornsby-Smith, An Introduction to Catholic Social Thought, Cambridge 2010, s. 106. Zob. także: S. Hellemans, Is There a Future for Catholic Social Teaching after the Waning of Ultramontane Mass Catholicism?, [w:] Catholic Social Thought: Twilight or Renaissance?, ed. J. Boswell, F.P. McHugh, J. Verstraeten, Paris 2000, s. 25-26.

35 Por. P.H. Sedgwick, The Market Economy and Christian Ethics, Cambridge-New York 1999, s. 251.

36 Encyklika papieża Jana Pawła II Sollicitudo rei socialis - Troska o sprawy społeczne, na 20-lecie encykliki Pawła VI Populorum progressio z 30 grudnia 1987 r., 42. Por. P.W. Salsich Jr., Toward a Property Ethic of Stewardship: A Religious Perspective, [w:] Property and Values: Alternatives to Public and Private Ownership, eds. Ch.C. Geisler, G. Dansker, Washington 2000, s. 31. 
Podobne stanowisko zajął papież Franciszek, który wprost odwołał się do nauczania Janowego zawartego w jego trzech wielkich encyklikach społecznych: Laborem exercens, Sollicitudo rei socialis i Centesimus annus ${ }^{37}$. Papież z Argentyny stwierdził, że współcześnie zarówno wierzący, jak i niewierzący zgadzają się co do tego, że ziemia jest dobrem wspólnym wszystkich ludzi, dlatego każdy projekt ekologiczny powinien włączać perspektywę społeczną uwzględniającą prawa podstawowe osób najbardziej społecznie upośledzonych. Należy zatem działać w oparciu o zasadę podporządkowania własności prywatnej powszechnemu przeznaczeniu dóbr, zasada ta jest bowiem fundamentem całego porządku społeczno-etycznego. Tradycja chrześcijańska nigdy nie uznała prawa do własności prywatnej za absolutne i nienaruszalne, podkreślała ona społeczną funkcję wszelkiej formy własności prywatnej. Absolutyzacja prawa własności prywatnej naruszałaby ludzką godność, a Kościół, chociaż nieustannie broni słusznego prawa własności, to równocześnie przypomina, że na właścicielu ciążą pewne obowiązki wobec społeczeństwa ${ }^{38}$.

Interesujące wypowiedzi papieża Franciszka dotyczą również kwestii postrzegania przez niego idei Karola Marksa. Papież we wstępie do zbioru pism Benedykta XVI, zatytułowanego Uwolnić wolność. Wiara i polityka w trzecim tysiącleciu, stwierdził jednoznacznie, że marksizm głosi błędne koncepcje, kwestionując fakt, że człowiek zależy od Boga. Franciszek podkreśla, że Benedykt XVI „wypracowuje i proponuje chrześcijańską wizję praw człowieka, zdolną zakwestionować na poziomie teoretycznym i praktycznym totalitarne żądania marksistowskiego państwa i ateistycznej ideologii, na której się opierało"39. Marksizm tkwi w błędzie, negując zależność człowieka od Stwórcy. Papież z Argentyny na poparcie swojego stanowiska przywołuje autorytet Jana Pawła II, dodając, że Benedykt XVI wiernie kroczył jego drogą. Apeluje, aby odrzucić ideologię, która neguje zasadniczą pewność, że człowiek istnieje jako mężczyzna i kobieta, którzy mają zadanie przekazywania życia. Franciszek przekonuje, że „te pozorne prawa człowieka, które nastawione są na jego autodestrukcję, mają wspólny mianownik, polegający na jednej wielkiej negacji; negowaniu zależności od miłości, tego, że człowiek jest stworzeniem Bożym powołanym z miłością przez Niego na Jego obraz" $^{40}$. Odrzucając roszczenia marksizmu, Franciszek stwierdza z naciskiem: „Kiedy neguje się zależność między stworzeniem i Stwórcą, tę relację miłości, w gruncie rzeczy rezygnuje się z prawdziwej wielkości człowieka, z ostoi jego wolności i godności” ${ }^{41}$. Tym samym z pełnym przekonaniem można stwierdzić, że obecny papież stoi na gruncie tradycyjnej katolickiej nauki o rodzinie.

37 Por. Laudato si, 93.

38 Ibidem.

39 Papież skrytykowat marksizm, http://niezalezna.pl/224416-papiez-skrytykowal-marksizm [dostęp: 6.05.2018].

40 Ibidem.

${ }^{41}$ Ibidem. 
Pewne istotne novum w wypowiedziach papieża Franciszka - w stosunku do jego poprzedników - przynosi konieczność ustosunkowania się do islamu. Potrzeba ta jest spowodowana napływem do Europy licznych rzesz muzułmańskich emigrantów, a także prześladowaniami chrześcijan w państwach muzułmańskich. Snop światła na stanowisko papieża $\mathrm{w}$ tej materii rzucają jego przemyślenia zawarte we wspomnianej rozmowie z D. Wolton. Na pytanie rozmówczyni, jak pomóc prześladowanym chrześcijanom, Franciszek odpowiada w sposób dziwnie wymijający ${ }^{42}$. Trudno zrozumieć to stanowisko, a jeszcze trudniej je wythumaczyć. Być może wynika ono z faktu, że obecny papież nie do końca rozumie fundamentalne założenia islamu. Na dalszych stronach apeluje bowiem, w kontekście prowadzenia dialogu z islamem, o krytyczne studium Koranu. Odnosząc się do tych słów papieża, należy przypomnieć, że bezwarunkowy szacunek dla tradycji, a zwłaszcza lęk przed podważeniem ustalonych dogmatów, doprowadził do tego, że muzułmanie zaakceptowali szczególne tabu - Koranu nie tylko się nie krytykuje, ale nie wolno go również interpretować. Jak zauważył Raszid Al-Maghribi, w całej historii islamu każdy, kto uważał, że Koran zawiera jedynie zwykłe opowieści, które można naśladować, narażał się na ogromne niebezpieczeństwo. Całe dzieje islamu dowodzą, że każdy, kto zlekceważy Koran jeśli nie okaże skruchy-może ponieść śmierćc ${ }^{43}$. Wydaje się, że papież postrzega możliwości wewnętrznej krytyki islamu z perspektywy chrześcijańskiej. Takie podejście dla ogromnej większości muzułmanów jest nie do przyjęcia, ponieważ wierzą oni, że islam - stworzona przez Allaha doskonała religia - nie może być krytykowany ${ }^{44}$.

$* * *$

Tych parę impresji, które przedstawiłem powyżej, upoważnia do kilku wniosków końcowych. Obecny papież, tak jak jego poprzednicy, za fundament papieskiego nauczania społecznego uważa idee dignitas humana i bonum com-

${ }^{42}$ Por. Franciszek (papież), D. Wolton, op. cit., s. 102.

43 Por. R. Al-Maghribi, Czy Koran jest słowem Bożym? Świadectwo nawrócenia muzutmanina, Poznań 2011, s. 237. O tym, że nie są to bezpodstawne groźby również w dzisiejszych czasach, przekonuje przypadek Nasra Hamida Abu Zajda, egipskiego semiologa z Uniwersytetu Al-Azhar. W latach 90. XX w. wystąpił on z propozycją interpretacji tekstów koranicznych w relacji do kontekstu historycznego i lingwistycznego czasu ich powstania. Uznał, że Koran został ogłoszony w kodzie językowym, który był w tym czasie używany, tym samym nie był objawieniem literalnym, lecz jedynie inspiracją „przełożoną” na język ludzki, którą trzeba analizować i studiować. Te poglądy były przyczyną oskarżenia Abu Zajda o odstępstwo od wiary, a w czerwcu $1995 \mathrm{r}$. ulemowie z Al-Azhar zażądali od rządu egipskiego zgodnej z szariatem kary śmierci przewidzianej dla odstępców od wiary. Abu Zajd i jego małżonka - należy dodać, że zgodnie z prawem muzułmańskim jako apostata nie miał prawa przebywać ze swoją (w tym momencie już byłą) żoną pod jednym dachem - aby pozostać razem, musieli ratować się ucieczką do Holandii. Por. G. Paolucci, C. Eid, Islam. Sto pytań. Odpowiada Samir Khalil Samir, Warszawa 2004.

${ }_{44}$ Szerzej na temat możliwości modernizacyjnych współczesnego islamu por. M. Sadowski, Islam. Religia i prawo, Warszawa 2017, passim. 
mune. To właśnie dzięki temu, że ludzie posiadają niezbywalną godność, przysługują im prawa człowieka. Papież odrzuca ideologię marksistowską i wzywa do chrześcijańskiego rozumienia własności prywatnej. Bardzo silny nacisk kładzie na ochronę środowiska naturalnego i wzywa do stosowania opcji preferencyjnej na rzecz ubogich. Opowiada się za tradycyjnym, katolickim rozumieniem rodziny jako związku mężczyzny i kobiety oraz akceptuje istniejące pomiędzy nimi różnice. Nie zawahał się też stwierdzić, że „Postmodernistycznym mężczyznom i kobietom nieustannie grozi skrajny indywidualizm, a wiele aktualnych problemów społecznych należy wiązać z egoistycznym poszukiwaniem natychmiastowej satysfakcji, z kryzysem więzi rodzinnych i społecznych, z trudnością w uznaniu innych"45.

Papież z Argentyny w dobie niezwykle silnego kryzysu migracyjnego wiele mówi o chrześcijańskim podejściu do problemu emigrantów, jest to jednak novum spowodowane okolicznościami, które nie występowały wcześniej z taką siłą. Tym samym zasadna jest teza, że nauczanie społeczne papieża Franciszka nie odbiega zasadniczo od nauczania jego poprzedników.

\section{BIBLIOGRAFIA}

Al-Maghribi R., Czy Koran jest słowem Bożym? Świadectwo nawrócenia muzułmanina, Poznań 2011.

Crolly H., Bergoglio studierte einst in Frankfurt am Main, www.welt.de/politik/deutschland/article114452124/Bergoglio-studierte-einst-in-Frankfurt-am-Main.html [dostęp: 4.04.2018].

Curran Ch.E., The Moral Theology of Pope John Paul II, Washington 2006.

Franciszek (papież), Wolton D., Otwieranie drzwi. Rozmowy o Kościele i świecie, Kraków 2018.

Hellemans S., Is There a Future for Catholic Social Teaching after the Waning of Ultramontane Mass Catholicism?, [w:] Catholic Social Thought: Twilight or Renaissance?, ed. J. Boswell, F.P. McHugh, J. Verstraeten, Paris 2000.

Himes K.R. OFM, Responses to 101 Questions on Catholic Social Teaching, New York 2001.

Hornsby-Smith M.P., An Introduction to Catholic Social Thought, Cambridge 2010.

Joyce M.S., The Voluntary Society and the Moral Order, [w:] A New Worldly Order: John Paul II and Human Freedom, ed. G. Weigel, Washington 1992.

Lehmkühler K., Inhabitatio: die Einwohnung Gottes im Menschen, Göttingen 2004.

Paolucci G., Eid C., Islam. Sto pytań. Odpowiada Samir Khalil Samir, Warszawa 2004.

Papież Pius XII, Con sempre nova freschezza - krucjata społeczna, orędzie na Boże Narodzenie, 24 grudnia 1942 r., https://ekai.pl/dokumenty/oredzie-na-boze-narodzenie-1942 [dostęp: 17.05.2019].

Papież skrytykowat marksizm, http://niezalezna.pl/224416-papiez-skrytykowal-marksizm [dostęp: 6.05.2018].

Sadowski M., Godność człowieka i dobro wspólne w papieskim nauczaniu społecznym (1878-2005), Wrocław 2010.

Sadowski M., Islam. Religia i prawo, Warszawa 2017.

Sadowski M., Państwo w doktrynie papieża Leona XIII, Wrocław 2002.

45 Laudato si, 162. 
Salsich P.W. Jr., Toward a Property Ethic of Stewardship: A Religious Perspective, [w:] Property and Values: Alternatives to Public and Private Ownership, eds. Ch.C. Geisler, G. Dansker, Washington 2000.

Scola A., Osoba ludzka. Antropologia teologiczna, Poznań 2005.

Sedgwick P.H., The Market Economy and Christian Ethics, Cambridge-New York 1999.

\section{SUMMARY}

The author of the article claims that Pope Francis, like his predecessors, sees the ideas of dignitas humana and bonum commune as the basis of social teaching, arguing that human rights stem from the inalienable human dignity. The pope rejects the Marxist ideology and appeals for the Christian understanding of private property. He stresses the need for environmental protection and calls for the use of the preferential option for the poor. Pope Francis also supports the traditional Catholic understanding of the marriage as a relationship between a man and a woman, while also emphasising the differences between them. When all is taken into account, it has to be observed that the pope's social teaching falls in line with that of his predecessors.

Keywords: papal social teaching; Pope Francis; human dignity; common good

\section{STRESZCZENIE}

Według autora artykułu papież Franciszek, tak jak jego poprzednicy, za fundament nauczania społecznego uważa idee dignitas humana i bonum commune. To właśnie dzięki temu, że ludzie posiadają niezbywalną godność, przysługują im prawa człowieka. Papież odrzuca ideologię marksistowską i apeluje o chrześcijańskie rozumienie własności prywatnej. Silny nacisk kładzie na ochronę środowiska naturalnego i wzywa do stosowania opcji preferencyjnej na rzecz ubogich. Opowiada się też za tradycyjnym, katolickim rozumieniem rodziny jako związku mężczyzny i kobiety oraz akceptuje istniejące pomiędzy nimi różnice. W oparciu o powyższe zasadna jest teza, że nauczanie społeczne papieża Franciszka nie odbiega zasadniczo od nauczania jego poprzedników.

Słowa kluczowe: papieskie nauczanie społeczne; papież Franciszek; godność człowieka; dobro wspólne 